\title{
PENINGKATAN PEMAHAMAN SISWA TENTANG POLA BILANGAN LONCAT DENGAN METODE PERMAINAN
}

\author{
Banniyatun \\ Guru kelas 1 SDN Pandanpuro 1 \\ banniyatun@gmail.com
}

\begin{abstract}
Abstrak
Penelitian ini bertujuan untuk mengetahui keefektifan penggunaan metode permainan loncat lantai untuk meningkatkan pemahaman siswa tentang pola bilangan pada siswa kelas satu SD Negeri Pandanpuro 1. Metode penelitian yang digunakan adalah penelitian tindakan kelas yang terdiri dari dua siklus. Setiap siklus dilaksanakan melalui empat tahap yaitu perencanaan, pelaksanaan, pengamatan, dan refeleksi. Pengumpulan data yang digunakan dengan tes evaluasi dan pengamatan pada saat pembelajaran berlangsung. Data yang diperoleh dianalisis secara deskriptif kualitatif. Berdasarkan penelitian penulis memperoleh hasil yaitu terjadi peningkatan pemahaman siswa tentang pola bilangan setelah menggunakan metode permainan loncat lantai. Hal ini terbukti dengan adanya peningkatan hasil evaluasi siswa yaitu pada data awal dengan nilai rata- rata 63.33; pada siklus I meningkat yaitu dengan nilai rata- rata 86.67; dan pada siklus II meningkat dengan nilai rata- rata 90 . Selain itu penggunaan metode permainan loncat lantai juga dapat meningkatkan motivasi belajar siswa. Siswa menjadi lebih aktif, antusias dan lebih konsentrasi dalam mengikuti pembelajaran di kelas karena pembelajaran yang disajikan menjadi lebih asik, menarik, dan menyenangkan. Berdasarkan penelitian tersebut penulis dapat menyimpulkan bahwa metode permainan loncat lantai dapat meningkatkan pemahaman siswa tentang pola bilangan pada siswa kelas 1 SD Negeri Pandanpuro 1 Kecamatan Pakem.
\end{abstract}

Kata kunci: Metode permainan, hasil belajar, motivasi.

\section{PENDAHULUAN}

Pendidikan di SD untuk anak usia 6 - 13 tahun, memiliki karakteristik siswa yang masih berada pada taraf berpikir konkret dan senang bermain. Oleh karena itu, guru dituntut untuk menggunakan media atau metode yang tepat dalam pembelajaran agar tercipta suasana belajar yang menyenangkan, sehingga siswa akan dapat mengembangkan kemampuan yang dimilikinya secara optimal.

Penggunaan suatu metode dan media yang kurang tepat dapat menjadikan mata pelajaran matematika menjadi sulit dipahami oleh siswa. Hal ini juga terjadi pada siswa kelas 1 SD Negeri Pandanpuro 1 Kecamatan Pakem Kabupaten 
Sleman pada materi pola bilangan. Hal ini terlihat dari 15 siswa baru 4 anak yang sudah memahami materi tentang pola bilangan loncat atau $26.7 \%$. Hal ini berarti $73.3 \%$ siswa belum memahami bilangan loncat. Hal ini dilihat dari nilai hasil ulangan siswa materi pola bilangan. Oleh karena itu peran guru sangat diperlukan untuk dapat memilih metode yang tepat dalam sebuah pembelajaran, sehingga pelajaran menjadi lebih mudah dipahami oleh siswa.

Siswa kurang berkonsentrasi dalam menerima pelajaran dikarenakan dari 15 siswa, 10 siswa adalah siswa laki- laki, dan 5 diantara mereka adalah siswa perempuan. Hal ini membuat suasana kelas menjadi ramai. Selain itu motivasi belajar siswa yang masih kurang karena pembelajaran yang disajikan guru kurang inovatif. Guru hanya menngunakan media batu sehingga membuat pembelajaran menjadi kurang menyenangkan dan membosankan. Selain itu pemanfaatan tutor sebaya juga belum optimal karena mereka masih ada yang memberitahukan jawaban dari sebuah soal, bukan langkah dalam mengerjakan soal. Hal ini membuat siswa menjadi tergantung dengan siswa lain.

Melihat kenyataan tersebut, untuk meningkatkan pemahaman siswa tentang pola bilangan loncat, maka penulis berupaya untuk melakukan perbaikan pembelajaran dengan cara melakukan penelitian dengan judul "Peningkatan Pemahaman Siswa tentang Pola Bilangan dengan Metode Permainan pada Siswa Kelas 1 SD Negeri Pandanpuro 1".

\section{Pengertian Belajar}

Belajar adalah suatu proses yang dilakukan individu untuk memperoleh suatu perubahan tingkah laku secara keseluruhan, sebagai hasil pengalaman individu itu sendiri dalam interaksi dengan lingkungan (Slameto,2003:2). Menurut Robert Gagne (Slameto, 2003: 15) belajar adalah suatu proses untuk memperoleh motivasi dalam pengetahuan, keterampilan yang diperoleh dari instruksi. Belajar dimulai dari masa bayi, yaitu belajar berbicara dan menggunakan bahasa.Penggunaan bahasa penting untuk belajar.

Belajar menurut Gagne dalam Dimyati \& Mudjiono (2009) merupakan kegiatan yang kompleks. Belajar terdiri dari tiga komponen penting, yaitu kondisi 
eksternal, kondisi internal, dan hasil belajar.Kondisi internal dan kondisi eksternal belajar bersifat interaktif. Oleh karena itu guru seyogyanya mengatur acara pembelajaran yang sesuai dengan fase- fase belajar dan hasil belajar yang dikehendaki.

Belajar dalam arti luas adalah perubahan tingkah laku yang dinyatakan dalam bentuk penguasaan, penggunaaan, penelitian, terhadap atau mengenai sikap, nilai- nilai, pengetahuan, dan kecakapan dasar yang terdapat dalam berbagai bidang sendi atau pengalaman yang terorganisir. Proses berarti serangkaian kejadian yang terdiri tahap demi tahap yang memungkinkan adanya interaksi antarindividu dengan suatu sikap nilai atau kebiasaan, pengetahuan dan keterampilan, dalam hubungannya dengan dunianya sehingga individu itu berubah. Belajar selalu menunjukkan suatu proses perubahan perilaku atau pribadi seseorang berdasarkan praktek atau pengalaman tertentu.

\section{Prinsip- prinsip belajar}

a. Perhatian dan motivasi

Perhatian mempunyai peranan penting dalam kegiatan belajar. Perhatian terhadap pelajaran akan timbul pada siswa apabila bahan pelajaran sesuai dengan kebutuhannya. Disamping perhatian motivasi mempunyai peranan penting karena motivasi adalah tenaga yang menggerakkan dan mengarahkan aktifitas seseorang menurut Gage \& Berliner dalam Dimyati dan Mudjiyono (2009).

b. Keaktifan

Menurut teori kognitif, belajar menujukkan adanya jiwa yang sangat aktif, jiwa mengolah informasi yang kita terima, tidak sekadar menyimpannya saja tanpa mengadakan trnsformasi menurut Gage \& Berliner dalam Dimyati dan Mudjiyono (2009). menurut teori ini anak memiliki sifat aktif, konstruktif, dan mampu merencanakan sesuatu.

c. Keterlibatan langsung/ berpengalaman

Belajar harus dilakukan sendiri oleh siswa, belajar tidak bisa dilimpahkan kepada orang lain. Dalam belajar melalui pengalaman langsung 
siswa tidak sekedar mengamati secara langsung tetapi ia harus menghayati, terlibat langsung dalam perbuatan, dan tanggung jawab terhadap hasilnya.

d. Pengulangan

Pentingnya prinsip pengulangan dalam belajar yaitu untuk melatih daya jiwa, membentuk respon yang benar dan kebiasaan- kebiasaan.

e. Tantangan

Penggunaan metode eksperimen, inkuiri, diskoveri, memberikan tantangan kepada siswa untuk belajar lebih giat dan sungguh- sungguh.

f. Balikan dan penguatan

Dengan balikan dan penguatan siswa akan belajar lebih bersemangat. Penguatan positif dan negatif dapat memperkuat belajar siswa.

g. Perbedaan Individual

Perbedaan individual berpengaruh pada cara dan hasil belajar siswa. Oleh karena itu perbedaan individu perlu diperhatikan oleh guru dalam upaya pembelajaran

\section{Karakteristik Siswa SD kelas rendah}

Anak kelas rendah menurut Piaget berada pada tahap operasional konkret, jadi untuk menyelesaikan suatu masalah perlu disertai hal- hal yang konkret dan nyata. Konkret yakni yang dapat dilihat, didengar, dibaui, diraba, yaitu dengan memanfaatkan lingkungan sebagai sumber belajar. Pemanfaatan lingkungan akan menghasilkan proses dan hasil belajar yang lebih bermakna dan bernilai, sebab siswa dihadapkan dengan peristiwa dan keadaan yang sebenarnya, keadaan yang alami, sehingga lebih nyata, lebih faktual, lebih bermakna, dan kebenarannya lebih dapat dipertanggungjawabkan.

Selain itu karena perkembangan kognitif siswa SD terutama siswa kelas 1 masih terikat dengan obyek konkret yang dapat ditangkap oleh panca indra, maka dalam pembelajaran siswa memerlukan alat bantu berupa media dan alat peraga yang dapat memperjelas apa yang akan disampaikan oleh guru sehingga lebih cepat dipahami dan dimengerti oleh siswa. 


\section{Belajar sambil Bermain}

Menurut Anggraini Adityasari (2013) bahwa dunia anak adalah bermain. Oleh karena itu kita bisa memanfaatkan saat- saat bermain untuk mengajarkan banyak hal termasuk matematika. Bermain bisa memberikan banyak manfaat bagi anak.Bermain bisa melatih motorik halus dan kasar pada anak. Selain itu dengan bermain bisa juga untuk mengembangkan logika dan rasa yaitu melatih otak kanan dan kiri. Bermain juga bisa mengembangkan karakter pada anak yaitu toleransi dan berbagi.

Belajar sambil bermain memberikan hak anak untuk bermain. Selain itu materi yang diberikan dapat diserap dengan baik karena ketika materi diberikan sambil bermain semua panca indera dan anggota tubuh terlibat. Sehingga ketika materi diulang kembali anak-anak tidak hanya mengandalkan otak saja untuk mengingat materi sebelumnya. Namun semua panca indera dan anggota tubuh yang terlibat saat materi diberikan seakan menjadi pembantu otak dalam menyegarkan ingatan.

Manfaat belajar sambil bermain seperti disebutkan sebelumnya, kompetensi akan mudah dicapai ketika otak tidak merasa terpaksa. Selain itu belajar sambil bermain menciptakan suasana pembelajaran yang menyenangkan. Sehingga anak-anak ingin mengulangi lagi belajar dan mereka tidak merasa terbebani karena pembelajaran menjadi hal yang menyenangkan bagi mereka. Efek jangka panjangnya anak-anak akan menjadi pembelajar yang baik.

Manfaat lain anak-anak akan tumbuh sehat baik jiwa mapun raganya. Jiwanya, karena hak mereka diberikan yaitu bermain. Sedangkan raganya anakanak akan bebas bergerak, sehingga masalah yang terkait dengan kegemukan (obesitas) dapat berkurang. Selain itu konsentrasi anak-anak dapat lebih diasah dengan berbagai permainan konsentrasi.

\section{Pembelajaran yang Menyenangkan}


Menurut Mulyasa, pembelajaran menyenangkan (joyfull instruction) merupakan suatu proses pembelajaran yang didalamnya terdapat suatu kohesi yang kuat antara guru dan siswa, tanpa ada perasaan terpaksa atau tertekan. Pembelajaran menyenangkan adalah adanya pola hubungan baik antara guru dengan siswa dalam proses pembelajaran. Guru memosisikan diri sebagai mitra belajar siswa, bahkan dalam hal tertentu tidak menutup kemungkinan guru belajar dari siswanya. Dalam hal ini perlu diciptakan suasana yang demokratis dan tidak ada beban, baik guru maupun siswa dalam melakukan proses pembelajaran. (Rusman, 2012: 326)

Pembelajaran dikatakan menyenangkan apabila di dalamnya terdapat suasana yang rileks, bebas dari tekanan, aman, menarik, bangkitnya minat belajar, adanya keterlibatan penuh, perhatian peserta didik tercurah, lingkungan belajar yang menarik, bersemangat,perasaan gembira, konsentrasi tinggi. Sementara sebaliknya pembelajaran menjadi tidak menyenangkan apabila suasana tertekan, perasaan terancam, perasaan menakutkan, merasa tidak berdaya, tidak bersemangat, malas/ tidak berminat, jenuh/ bosan, suasana pembelajaran monoton, pembelajaran tidak menarik siswa (Indrawati\&Setiawan, 2009: 24).

Untuk mewujudkan proses pembelajaran yang menyenagkan, guru harus mampu merancang pembelajaran dengan baik, memilih materi yang tepat, serta memilih dan mengembangkan strategi yang dapat melibatkan siswa secara optimal.

\section{Pengertian Matematika}

Matematika sebagai salah satu ilmu dasar yang sudah menjadi alat untuk mempelajari ilmu- ilmu yang lain. Oleh karena itu penguasaan terhadap matematika mutlak diperlukan dan konsep- konsep matematika harus dipahami dengan betul dan benar sejak dini. Hal ini karena konsep- konsep dalam matematika merupakan suatu rangkaian sebab akibat.

Menurut Kamus Besar Bahasa Indonesia (2002:566) matematika diartikan sebagai ilmu pengetahuan tentang bilangan, hubungan antara bilangan dengan prosedur operasional yang digunakan dalam penyelesaian mengenai bilangan. 
Menurut Kamus Matematika (2003) matematika adalah pengkajian logismengenai bentuk, susunan, besaran, dan konsep- konsep yang berkaitan. Sebagai pengetahuan matematika mempunyai ciri- ciri khusus antara lain abstrak, deduktif, konsisten, hierarkis, dan logis.

Matematika menurut Ruseffendi (1991) dalam Heruman (2012), adalah bahasa symbol; ilmu deduktif yang tidak menerima pembuktian secara induktif; ilmu tentang pola keteraturan, dan struktur yang terorganisasi, mulai dari unsure yang tidak didefinisikan, ke unsure yang didefinisikan, ke aksioma atau postulat, dan akhirnya ke dalil.

Menurut Soedarinah \& Maryana (1991:65) matematika adalah "pengetahuan yang bersifat hirarkis, artinya tersusun dalam urutan tertentu, bermula dari urutan yang sederhana kemudian menuju ke hal yang rumit, bermula dari hal yang konkret menuju hal yang abstrak."

\section{Proses Pembelajaran Matematika di Kelas Rendah}

Kondisi belajar mengajar yang efektif digunakan untuk mengembangkan kreativitas dan kompetensi siswa. Kondisi belajar yang efektif ditandai dengan adanya minat dan perhatian siswa dalam belajar. Keterlibatan siswa dalam belajar dipengaruhi oleh sifat-sifat murid, baik yang bersifat kognitif seperti kecerdasan dan bakat maupun yang bersifat afektif seperti motivasi, rasa percaya diri, dan minatnya.

Konsep- konsep pada kurikulum matematika SD dapat dibagi menjadi tiga kelompok besar yaitu penanaman konsep dasar, pemahaman konsep dan pembinaan keterampilan Heruman (2012:2).

Dalam kegiatan pembelajaran matematika si SD, guru harus dapat mengkreasikan suatu lingkungan belajar yang memupuk perkembangan setiap kekuatan matematika siswanya dengan: (1) memberikan dan mengelola waktu yang cukup untuk mengeksplorasi konsep dan prosedur matematika yang sedang dipelajari siswa, dan untuk menemukan ide-ide yang berarti, (2) menggunakan alat peraga yang dapat mempermudah siswa, (3) memberikan konteks yang dapat 
mendorong perkembangan dan kecakapan matematika siswa, (4) menghargai dan menilai gagasan-gagasan, cara berfikir, dan watak matematis siswa.

Pada proses belajar matematika, menurut Bruner dalam Gatot Muhsetyo dkk (2011) menyatakan pentingnya tekanan pada kemampuan peserta didik dalam berfikir intuitif dan analitik akan mencerdaskan peserta didik membuat prediksi dan terampil dalam menemukan pola (pattern) dan hubungan/keterkaitan (relations). Pembauran dalam proses belajar ini, dari proses drill \& practice ke proses bermakna, dan dilanjutkan proses berpikir intuitif dan analitik, merupakan usaha luar biasa untuk selalu meningkatkan mutu pembelajaran matematika.

\section{METODE}

Pelaksanaan penelitian ini dilakukan dalam dua siklus. Setiap siklus terdiri dari empat tahap yaitu perencanaan, pelaksanaan, pengamatan/ pengumpulan data/ instrumen, dan refleksi.

Penelitian ini dilakukan pada siswa kelas 1 SD Negeri Pandanpuro 1. Prosedur penelitian ini secara garis besar yaitu perencanaan, pelaksanaan, pengamatan, dan refleksi.

Teknik yang digunakan untuk mengumpulkan data yaitu tes dan non tes, berupa observasi. Analisis data dalam penelitian ini disajikan dalam bentuk analisis kualitatif dengan metode pemaparan secara deskriptif komparatif .

\section{HASIL PENELITIAN DAN PEMBAHASAN}

Kegiatan pembelajaran pada siklus I yaitu pembelajaran matematika tentang bilangan loncat.Hasil pengamatan tentang motivasi belajar siswa dalam kegiatan pembelajaran pada siklus I dapat dideskripsikan bahwa selama kegiatan pembelajaran dengan metode permaianan loncat lantai ternyata siswa berperan aktif dalam pembelajaran, siswa tertarik dengan media yang digunakan, siswa lebih antusias mengikuti pembelajaran, dan konsentrasi siswa bisa lebih terkendali.

Berdasarkan refleksi hasil pembelajaran dengan menggunakan metode permainan loncat lantai, dapat dikemukakan beberapa kekurangan yang dapat 
digunakan sebagai acuan untuk kegiatan siklus berikutnya. Kelemahan pada siklus pertama antara lain: Siswa masih berebut ketika diberi tugas untuk mencari bilangan loncat dengan metode permainan, Siswa masih ada yang kurang memperhatikan penjelasan guru, Siswa masih ada yang kurang bertanggung jawab terhadap tugas yang diberikan guru

Kelebihan pembelajaran matematika pada siklus pertama ini adalah siswa lebih tertarik dalam memperhatikan pelajaran dengan metode permainan loncat lantai, Siswa merasa senang karena mereka belajar sambil bermain, Sebagian besar siswa antusias dalam mengerjakan tugas dari guru, Siswa menjadi lebih aktif mengikuti pelajaran, Hasil belajar siswa meningkat setelah menggunakan metode permainan loncat lantai

Berdasarkan hasil refleksi pada siklus I ini maka pada siklus II ini peneliti menyusun rencana perbaikan pembelajaran dengan memperhatikan kekurangan serta kelemahan pada siklus I. Metode yang digunakan masih sama dengan siklus I yaitu metode permainan loncat lantai. Pada siklus II ini metode permainan loncat lantai dengan pengelompokkan, untuk melatih tanggung jawab siswa terhadap tugas yang diberikan guru dan menghindari adanya siswa yang berebut. Selain itu peneliti juga menyiapkan lembar observasi dan lembar evaluasi.

Berdasarkan pengamatan kegiatan pembelajaran yang dilakukan pada siklus II tentang bilangan loncat yaitu siswa lebih termotivasi dalam mengikuti pembelajaran, sehingga siswa dapat berperan aktif dalam pembelajaran. Selain itu konsentrasi siswa menjadi lebih terkendali. Dengan adanya pengelompokkan maka siswa tidak berebut untuk mencari bilangan loncat. Selain itu siswa bisa bekerja sama dalam kelompok.

Berdasarkan hasil penelitian diketahui bahwa terdapat peningkatan hasil belajar matematika materi bilangan loncat setelah tindakan diberikan pada siklus I dan siklus II. Pada siklus II terdapat beberapa siswa yang nilainya menurun, namun rata- rata kelas dan ketuntasan siswa meningkat.Hal ini terlihat dari hasil evaluasi siswa bahwa sebanyak 14 siswa dapat memperoleh nilai lebih dari 70 atau tuntas belajar. Maka hasil evaluasi dianalisis dan dideskripsikan dalam 
pemaparan berikut ini.Adapun data- data perbandingan nilai siswa dapat dilihat sebagai berikut.

Tabel 1. Data Perkembangan Nilai Siswa

\begin{tabular}{ccccc}
\multirow{2}{*}{ No } & Rentang Nilai & \multicolumn{3}{c}{ Jumlah Siswa } \\
\cline { 3 - 5 } & & Data Awal & Siklus I & Siklus II \\
\hline 1 & $0-10$ & 1 & 1 & 0 \\
\hline 2 & $11-20$ & 0 & 0 & 0 \\
\hline 3 & $21-30$ & 0 & 0 & 0 \\
\hline 4 & $31-40$ & 0 & 2 & 0 \\
\hline 5 & $41-50$ & 3 & 0 & 0 \\
\hline 6 & $51-60$ & 3 & 1 & 0 \\
\hline 7 & $61-70$ & 4 & 0 & 1 \\
\hline 8 & $71-80$ & 2 & 2 & 5 \\
\hline 9 & $81-90$ & 2 & 1 & 3 \\
\hline 10 & $91-100$ & 0 & 8 & 6 \\
\hline & JUMLAH & & 15 & 15
\end{tabular}

Dari tabel di atas dapat dijelaskan dalam bentuk grafik seperti berikut.

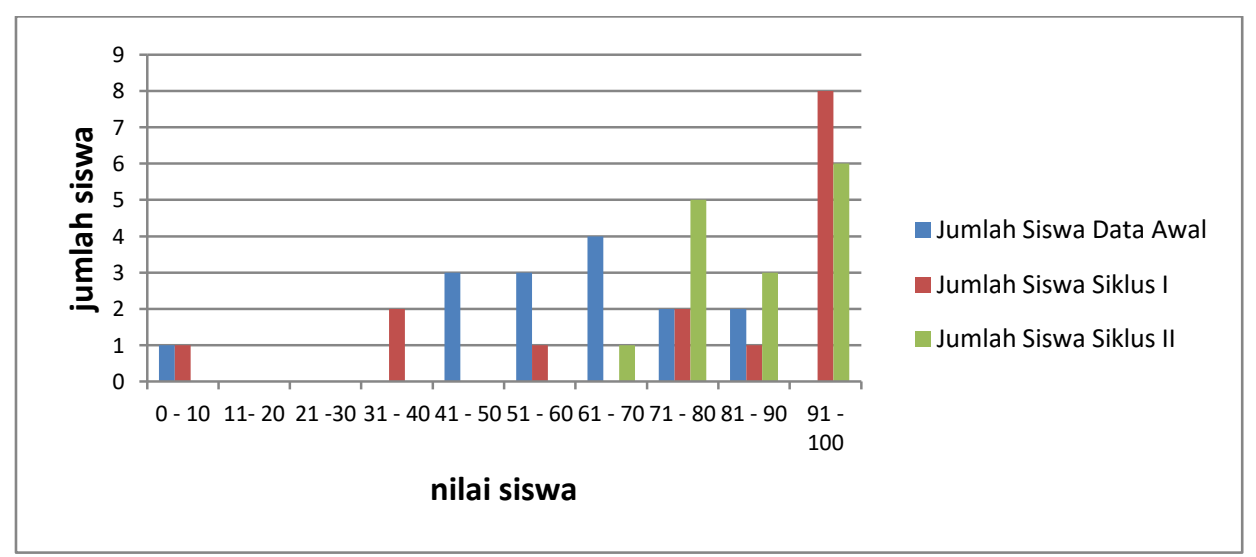

Gambar 1. Grafik Perbandingan Nilai Siswa Antar Siklus

Berdasarkan table dan grafik di atas dapat dijelaskan bahwa pada pra siklus atau sebelum tindakan baru 4 anak yang sudah mendapat nilai diatas 70 yaitu $26,7 \%$, pada siklus I siswa yangmemperoleh nilai diatas 70 meningkat 
menjadi 11 siswa yaitu 73,3\%, dan pada siklus II siswa yang mendapat nilai diatas 70 meningkat lagi menjadi 14 siswa yaitu 93,3\%.

Pembelajaran matematika tentang bilangan loncat dengan metode permainan loncat lantai pada siswa kelas I SD Negeri Pandanpuro 1 menunjukkan hasil belajar yang lebih efektif. Dengan melihat perkembangan nilai berdasarkan grafik di atas dapat dikatakan bahwa ada perbedaan yang signifikan dari prestasi belajar siswa antara sebelum tindakan dan sesudah tindakan pada siklus I dan II.

\section{SIMPULAN}

Berdasarkan hasil pembahasan dalam penelitian ini dapat ditarik kesimpulan bahwa, penerapan metode permainan loncat lantai lebih efektif untuk meningkatkan pemahaman siswa kelas I tentang bilangan loncat pada siswa kelas 1 SD N Pandanpuro 1. Hal ini terbukti dengan adanya peningkatan hasil evaluasi siswa setelah menggunakan metode permainan loncat lantai, yaitu pada data awal dengan nilai rata- rata 63.33; pada siklus I dengan rata- rata 86.67; dan pada siklus II dengan rata- rata 90. Selain itu penggunaan metode permainan loncat lantai juga dapat meningkatkan motivasi belajar siswa. Hal ini terlihat dari antusias dan konsentrasi siswa dalam mengikuti pembelajaran, karena pembelajaran menjadi lebih menyenangkan.

\section{DAFTAR PUSTAKA}

Adityasari, Anggraini.(2013). Main Matematika Yuk. Jakarta: PT Gramedia Pustaka Utama.

Depdiknas.(2002). Kamus Besar Bahasa Indonesia Edisi Ketiga. Jakarta: Balai Pustaka.

Dimyati \& Mudjiono.(2009). Belajar dan Pembelajaran. Jakarta: PT RinekaCipta.

Heruman.(2012). Model Pembelajaran Matematika di Sekolah Dasar. Bandung: PT RemajaRosdakarya. 
Indrawati dan Wawan Setiawan.(2009). Pembelajaran Aktif, Kreatif, Efektif, dan Menyenangkan. Jakarta: Pusat Pengembangan dan Pemberdayaan endidik dan Tenaga Kependidikan Ilmu Pengetahuan Alam (PPPPTK IPA).

Kerami, Djati. (2003). KamusMatematika. Jakarta: Balai Pustaka.

Muhsetyo, Gatot dkk. (2011). Pembelajaran Matematika SD. Jakarta: Universitas Terbuka.

Rusman.(2012). Model- Model Pembelajaran. Jakarta: PT Raja GrafindoPersada.

Slameto.(2003). Belajar dan Faktor-Faktor Yang Mempengaruhinya. PT. Jakarta: Rineka Cipta.

Soedarinah dan Maryana. (1991). Pengelolaan Kelas dan Interaksi Belajar Mengajar. Surakarta: UNS Press 